\title{
Green Mission Game for the Forest Preservation Campaig
}

\author{
Nuryanti \\ yanti7566@gmail.com \\ Information Systems Department, Faculty of Computer Science \\ Soegijapranata Catholic University, Indonesia \\ Ridwan Sanjaya \\ ridwan@unika.ac.id \\ Information Systems Department, Faculty of Computer Science \\ Soegijapranata Catholic University, Indonesia \\ FX. Hendra Prasetya \\ hendra@unika.ac.id \\ Information Systems Department, Faculty of Computer Science \\ Soegijapranata Catholic University, Indonesia
}

Abstract-Forest have an important role for living thing, like human, animal, or plants. For example, forests play an active role in the availability of water sources that participated maintain food security for living beings and the largest supplier of oxygen. However, the lack of human consciousness in maintaining forest ecosystems resulted in the emergence of several threats that cause forest destruction in the form of deforestation and degradation include illegal logging, forest fires, forest conversion for plantations and industries [3]. With game application: Green Mission, it is be expected to be one of the solutions and can answer the problem for dealing with the forest damage. Application Green Mission is supposed to educate about the importance of conserving forest by planting trees. In this game, players are directed to resolve some of the challenges in the form of putting out fires, replant the forest bare, and drove the actors of deforestation. The concept in an adventure game is supposed to give a pleasant impression beside to educate player.

Keywords: Forests, Trees, Illegal Logging, Game

\section{INTRODUCTION}

Forests have many useful benefits for the community. One of them is the various types of trees that can be utilized for human needs, both as building materials and daily equipment (pharmaceutical/craft industry), tourism, and science. [2] Also, forest ecosystems participate in providing protection, as a livelihood, as suppliers of water, fuel and maintaining food security for 2 billion people. [1]

One of the functions of tropical forest itself is to absorb carbon dioxide gas emissions to be converted into oxygen. The oxygen produced itself depends on the type of tree, the age of the tree, and the environmental conditions of the tree grow. Every one year old tree can produce approximately $1.2 \mathrm{~kg}$ of oxygen per day. [3] Trees with a height of 100 feet and a diameter of $18 \mathrm{~cm}$ can produce 6,000 pounds of oxygen. [4] For rubber tree species, each leaf that performs photosynthesis produces oxygen at $5 \mathrm{ml} / \mathrm{hr}$. The number of rubber tree leaves is approximately 200 sheets where each hectare of rubber forest has about 300 trees. So the oxygen produced approximately 300 liters per hour. At the time of rest, humans breathe oxygen about 1.8 to 2.4 grams of oxygen per minute. [5] 
However, despite the diversity of ecosystems and high forest functions, forests have many threats, one of which is deforestation that includes illegal logging, forest fires, forest conversion into plantations and industries. The needs of the timber industry alone are about 80 million cubic meters used to meet the chainsaw, plywood, paper, and pulp industries. [2] When 27 thousand trees are cut down per day, the oxygen loses $32.400 \mathrm{~kg}$ of oxygen each day. [3]

The destruction of forest ecosystems led to approximately 1 billion people suffering from hunger, 768 living without safe water supplies, and 1.4 billion people have no access to electricity for about 2 billion human population swelling from 7.2 billion in 2013 to 9, 2 billion in 2050. [1]

One way to educate the importance of forests is through technology, one of them with the making of games. The reason for the use of the game as a solution that is because of the rapid development of technology that makes it easier to educate the public about the importance of maintaining forest sustainability.

\section{THEORETICAL FOUNDATION}

\subsection{Forest Rehabilitation Effort}

As mentioned in article 42 paragraph 1 mentioned that the effort of rehabilitation on forest that can be done in the form of reforestation and greening activity [6] Reforestation is an attempt to rehabilitate forests by replanting degraded or deforested forests due to excessive logging and their execution being carried out on forest areas falling into the category of state forests such as protected forests and production forests. Generally, reforestation activities are carried out by planting the forest area with tree species that can be utilized by the community. While reforestation is the planting done in areas that were not former forests or outside state forest areas.

\subsection{Purpose Of Rehabilitation}

The objectives of forest rehabilitation are for conservation of soil and water, increased productivity of forests and land, as well as efforts to improve the level of community welfare. [7]

\section{Soil and water conservation}

Efforts to maintain, rehabilitate, and improve land use capacity by land use classification. The objective is to increase land productivity and reduce the negative impacts of land management. Soil and water conservation is carried out in protected forests and conservation forests. For protected forests the purpose of improving ecological functions, while conservation forests to conserve biodiversity.

2. Forest and land productivity

This activity aims to aim to restore the productivity and ecosystems of forests and their implementation by using fastgrowing tree species

3. Improve the welfare level

With rehabilitation, it can be useful for communities to improve forest and land cover, produce timber, protect watersheds as a means of maintaining the ecological functions of the forest to meet the timber needs.

\subsection{Benefits of Planting Trees}

Some of the advantages gained when planting trees include: [8]

1. An adult tree can help reduce water runoff in urban areas. The average adult tree can absorb water up to 1,000 gallons of rainfall.

2. The tree absorbs ozone

3. A tree can store energy

4. Trees can be used as windbreaks

\subsection{Game}

According to Roger Cailois, in his book Man, Play, and Games it is mentioned that something is said to be a game when it encompasses activities that have the following characteristics: [9] 
a. Free

b. Separate

c. Uncertain

d. Unproductive

e. Governed by rules

f. Make belief

\subsection{Construct 2}

Construct 2 is an HTML5-based game editor that has many features. Anyone can make a game without having to have programming experience because in Construct 2 the principle just drags and drop it by using visual editor and system-based logic behavior.

Here are some advantages of using Construct 2 are: [10]

\section{Multiple platforms}

Games can be published through desktop computers (PC, Mac, or Linux), via mobile platforms (Android, iOS, Blackberry, Windows Phone 8.0, Tizen), and through HTML5 based websites.

2. No programming required

Construct two does not use a programming language that is difficult to understand. Instead, it will make gaming easier for people who do not have programming experience.

3. Built-in Physics

Construct two does not use complicated physics functions, so Construct two is easy to use.

4. Can be expanded

Construct two is also developed by third parties to add new functionality to make the game more beautiful and interesting.

\subsection{Android}

Android is an operating system for touchscreen mobile devices such as smartphones and based on open source that allows software to be freely modified and distributed by developers and application developers. Android Inc first developed Android, then purchased by Gooogle and inaugurated in 2005. Android is a widely used operating system in the world, beating the Symbian operating system. So the choice of operating system for companies engaged in technology and develop it as an additional application not only on smartphones but also on television, digital cameras, and other electronic devices.

\section{METHODS}

\subsection{Needs Analysis}

Techniques in the needs analysis obtained from the observation of games with a similar theme include:

\section{a. Si Bolang Dayak Reboisasi}

Is a game that tells the story of a child who must do forest reforestation, especially in the area of Kalimantan. This game is built using the framework MDA (Mechanics, Dynamics, Aesthetic)

b. Edugame "Selamatkan Hutan Indonesia" Is a game based on Unity 3D? [4]

\subsection{Game Design}

The design of this game is called Green Mission which is expected to be one of the campaign media for forest conservation. Here's the design flow of Green Mission:

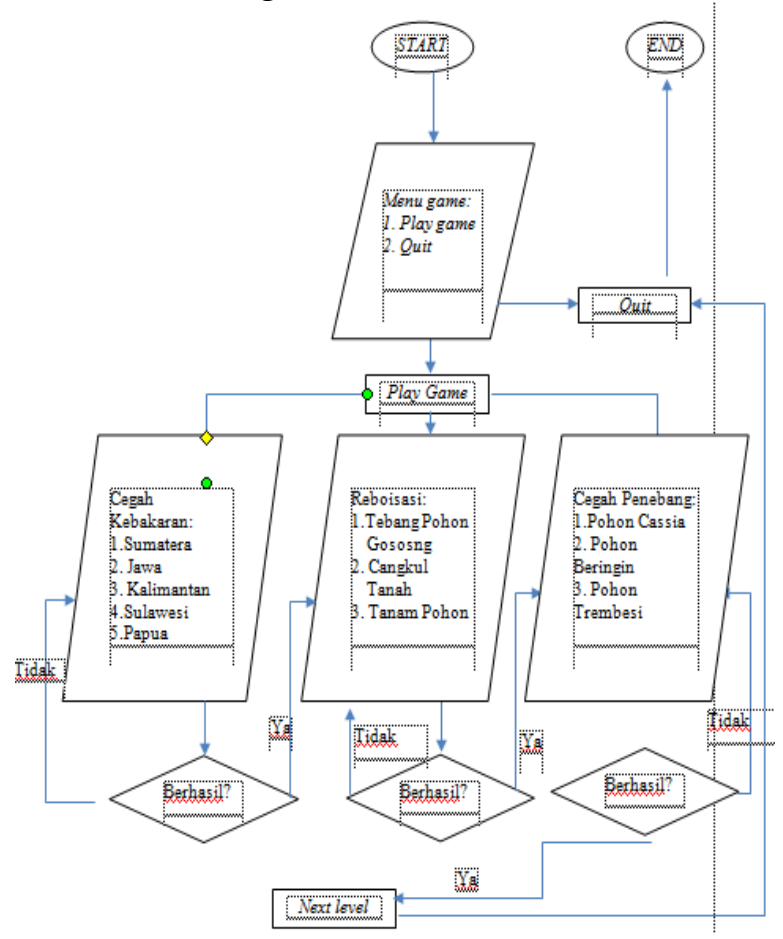

Figure 1. Interface display of menu options 


\subsection{Interface Implementation}

Here is the interface in the form of laying the main menus and buttons used in the Green Mission game:

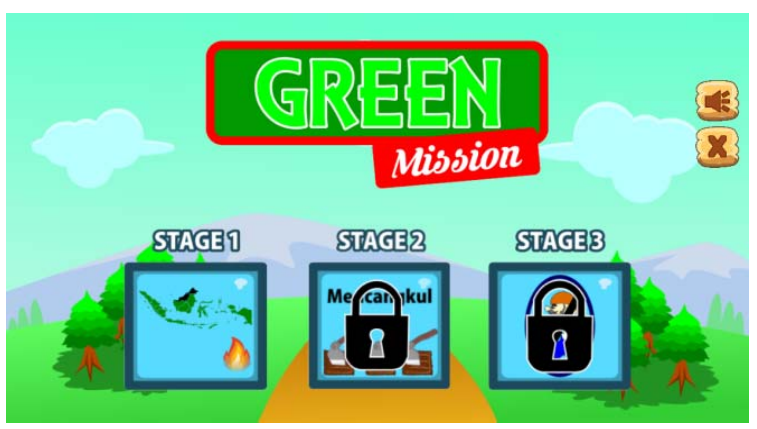

Figure 2. Interface display of menu options

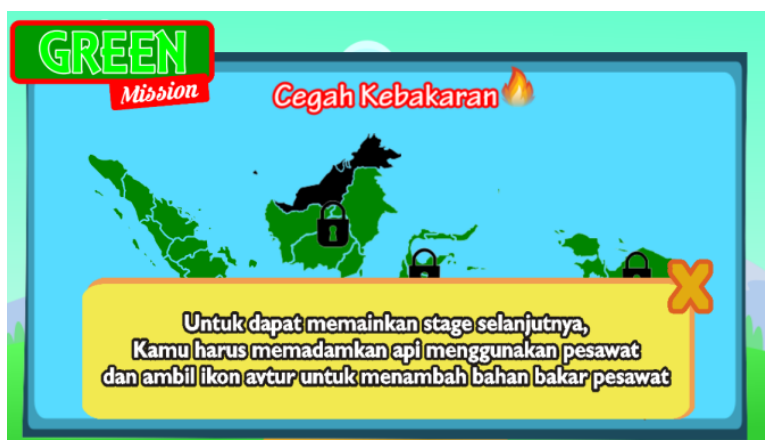

Figure 3. Display interface 1st stage menu option

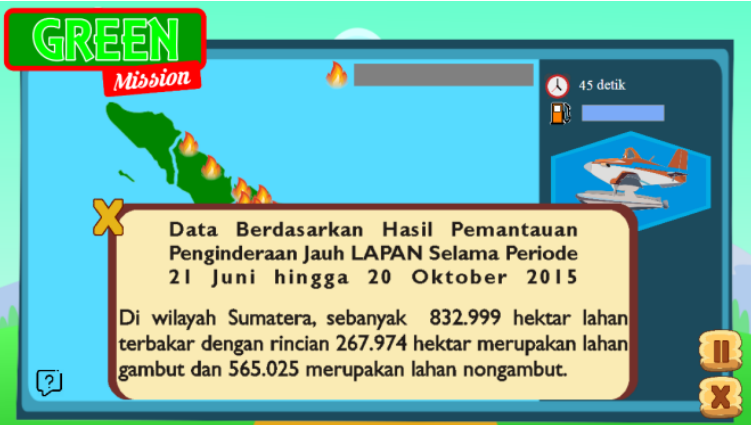

Figure 4. Display interface fire information Pop Up
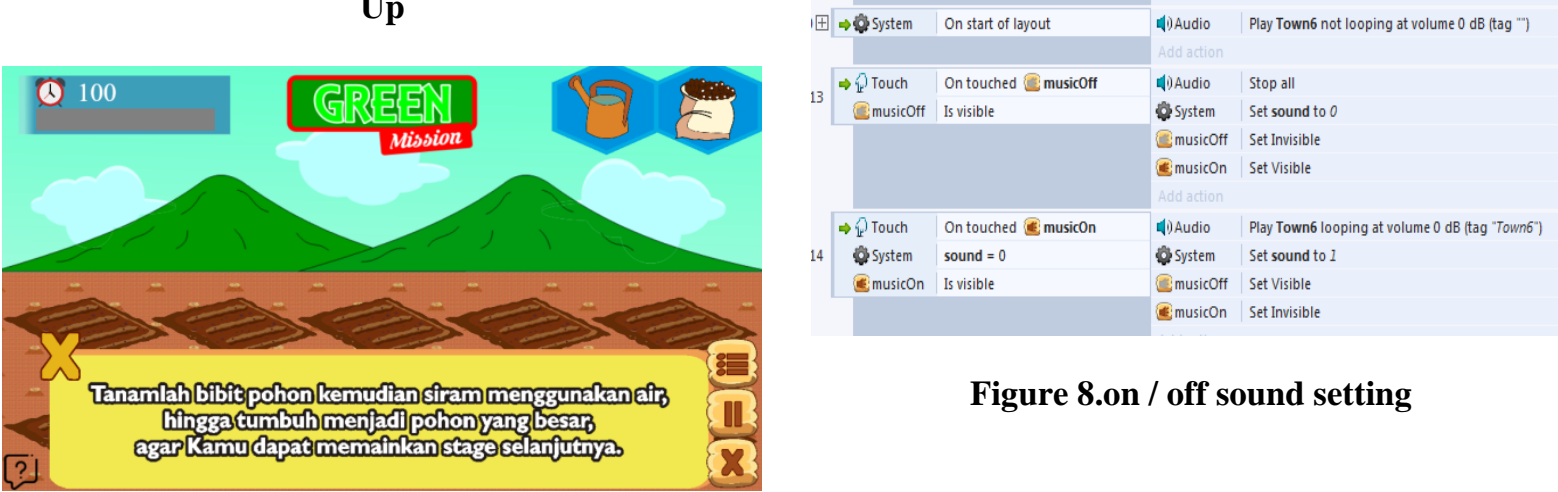

Figure 8.on / off sound setting

Figure 5. Stage 2 interface display 


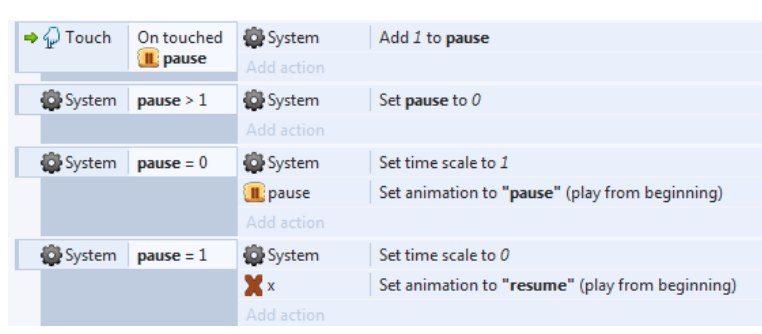

Figure 9. Pause button programming

\section{SURVEY RESULTS}

In this study using questionnaires in the form of pre-test and post-test. The pre-test is used for the preparation of game concepts. The post-test is used to determine whether the game is made to solve the problem. The results of processing the 30 questionnaires are:

1. $93.3 \%$ (28 respondents) agreed that the Green Mission interesting. 6.7\% (2 respondents) stated neutrally about their interest in Green Mission. The neutral meaning here states between Agree and Disagree.

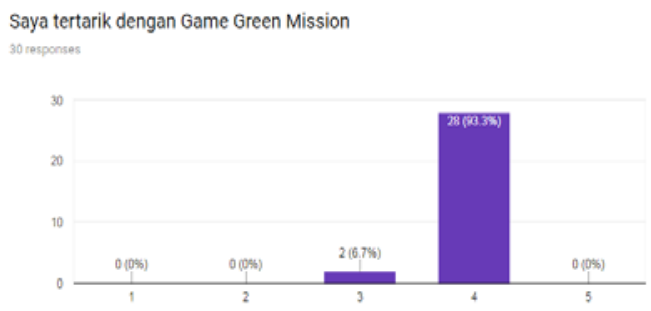

Figure 10. Stem Diagram of Interest in Green Mission

2. $93.3 \%$ (28 respondents) agreed that the Green Mission storyline is interesting. $6.7 \%$ (2 respondents) stated neutrally about the storyline presented. The neutral meaning here states between Agree and Disagree.

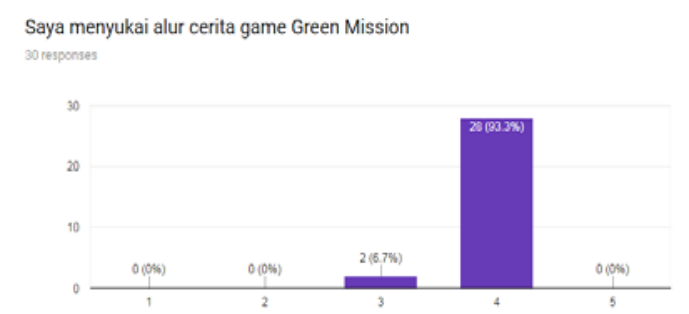

Figure 11. Stem Diagram Interest in the Green Mission storyline
3. $46.7 \%$ (14 respondents) agreed that Pop $\mathrm{Up}$ information provides additional knowledge about forests. 33.3\% (10 respondents) stated strongly agree that the Pop provided provides additional knowledge. While 20\% (6 respondents) stated neutrally.

Pop Up luas kebakaran yang disajikan pada game Green Mission menambah pengetahuan tentang hutan

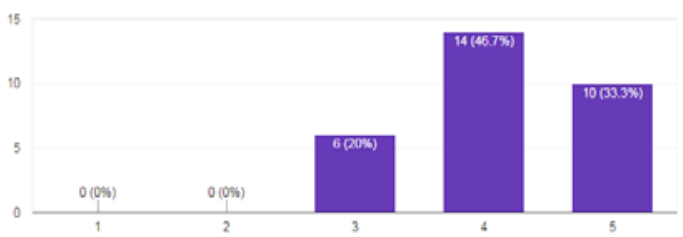

Figure 12. Pop-up Diagram of Fire Up

4. $72.4 \%$ (21 respondents) stated that Green Mission is easy to play. 3.4\% (1 respondent) stated strongly agree. And 24.1\% (7 respondents) stated neutral.

Game Green Mission mudah dimainkan

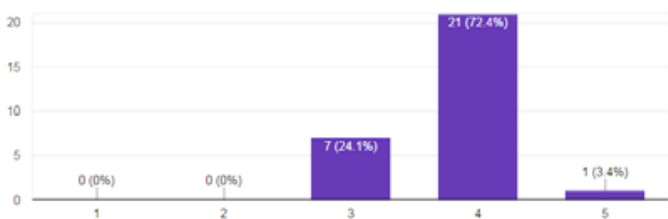

Figure 13. The Green Mission is easy to play

5. 70\% (21 respondents) agreed that Green Mission could be used as media of forest conservation campaign. $\quad 23.3 \% \quad$ (7 respondents) stated strongly agree. While $6.7 \%$ (2 respondents) declare neutral if the Green Mission be a media campaign forest conservation.

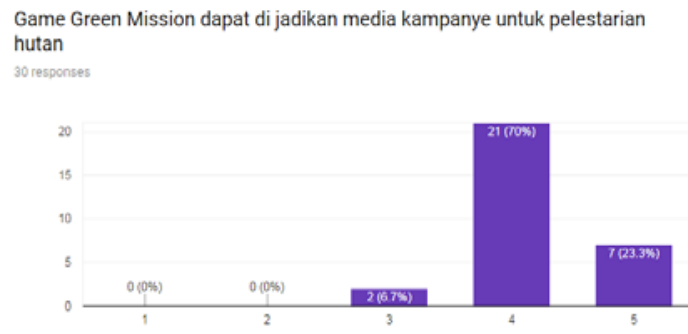

Figure 14. Bar Diagram of Green Mission media campaign 


\section{CONCLUSION}

Green Mission is an educational game intended for the general public informed of the forest. Game design is made simple without adding many objects. The design is more focused on the core game carried. For more objects, the focus is on the core of the titles of each stage. The first stage is entitled "Cegah Kebakaran."The design of the stage is focused on the fire element and the element of the plane where the two objects become the key is to complete stage 1 . For the second stage entitled "Mencangkul/Reboisasi," the design is focused on the process of ground grinding and forest replanting. Meanwhile, the third stage entitled "Cegah Penebang" focused on enemy elements that became the main character of forest destruction occurred. Each stage has three sublevels in it with a continuous storyline.

Provision of additional information on the extent of forest fires in stage 1 explains the different information in each island.

\section{ACKNOWLEDGMENT}

I am very grateful to the lecturers of Information Systems Department, Faculty of Computer ScienceSoegijapranata Catholic University who has guided my studies and Gedawang people who have helped in the completion of this thesis.

\section{REFERENCES}

[1] WWF, “Report 2014,”Jakarta, 2014.

[2] WWF, “The Fact Sheets,” Jakarta, 2007.

[3] A. Said, Hidup Sukses Cara Saints. Elex Media Komputindo.2011

[4] A. Gunanto, “Jurnal Fix,” pp. 1-94, 2010.

[5] R. Rencana and P. Integratif, "RPPI (Rencana Penelitian dan Pengembangan Integratif),” pp. 1-14, 2014.

[6] P. R. Indonesia, "Undang Undang No. 41 Tahun 1999 Tentang: Kehutanan,” Sekr. Negara. Jakarta, 1999.
[7] A. A. Nawir, A. A. M. R. L. Nawir, L. Rumboko, and C. I. F. Research, "Rehabilitasi hutan di Indonesia: akan kemanakah arahnya setelah lebih dari tiga dasawarsa?"Center for International Forestry Research, 2008.

[8] A. Ipcc, "Laporan AR-5 Working Group I Press Release Panel Change ( IPCC )," no. 0, pp. 0-4, 2013.

[9] R. Caillois and M. Barash, Man, Play, and Games. University of Illinois Press, 1961.

[10]A. Subagio, Learning Construct 2. Packt Publishing, 2014. 